\title{
A new red colonial Pseudanabaena (Cyanoprokaryota, Oscillatoriales) from North American large lakes
}

\author{
Hedy J. Kuing ${ }^{1 *}$, H. Dail Laughinghouse IV $^{2,3}$, Jan S̆MArda ${ }^{4}$, Jiří KomÁreK ${ }^{5}$, Judy

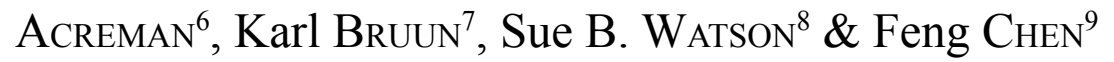

${ }^{1}$ Algal Taxonomy and Ecology Inc. Winnipeg, Manitoba, Canada; *Corresponding author e-mail: hkling@mts. net

${ }^{2}$ MEES Program, College of Computer, Mathematical and Natural Sciences, University of Maryland, College Park, MD, USA

${ }^{3}$ Department of Botany, National Museum of Natural History, Smithsonian Institution, Washington, DC, USA

${ }^{4}$ Department of Biology, Fakulty of Medicine, Masaryk University, University Campus, Kamenice 5, CZ-625 00 Brno - Bohunice, Czech Republic

${ }^{5}$ Institute of Botany AS CR, Dukelská 135, Třeboň, Czech Republic

${ }^{6}$ Canadian Phycological Culture Centre (CPCC), Department of Biology, University of Waterloo, 200 University Ave West, Waterloo, ON Canada

${ }^{7}$ Nostoca Algae Laboratory, 7770 Springridge Road N.E., Bainbridge Island, WA USA

${ }^{8}$ National Water Research Institute, 867 Lakeshore Road, Burlington, ON Canada

${ }^{9}$ Institute of Marine and Environmental Technology, University of Maryland Center for Environmental Science, Baltimore, MD USA

\begin{abstract}
A new morphotype of the genus Pseudanabaena (Cyanoprokaryota, Oscillatoriales) was identified from bloom samples of Aphanizomenon flos-aquae RALFs ex BorNet et FlAHAULt taken from large central North American water bodies, Lake Winnipeg (LWPG) and Lake of the Woods (LOW), which drains into Lake Winnipeg (Fig. 1) and a strain of this morphotype was isolated from LOW in the fall of 2009. Here we describe the morphology and basic ecology, cytology and phylogenetic position of this new chromatic adaptive and colony forming planktonic species and propose a new species Pseudanabaena rutilus-viridis KLING et al. Preliminary research has indicated that it has the ability to produce the toxin microcystin and further research is under way to assess its ability to produce taste-odour and other toxins and nitrogen-fixing capacity.
\end{abstract}

Key words: Cyanoprokaryotes, Oscillatoriales, Pseudanabaena, taxonomy, morphology, cytology, genetics, ecology, toxins

\section{Introduction}

The morphologically variable (Romo \& MiRACLE 1994) genus Pseudanabaena, established in 1915 by LAUTERBORN, revised by ANAGNOSTIDIS \& KOMÁREK (1988; KOMÁREK 2003) is closely related genetically and morphologically to the genus Limnothrix MEFFERT. Further molecular work by AcINiAs et al. (2009), using the 16S-23S internal transcribed unit (ITS) confirmed that some of the morphotypes assigned to Pseudanabaena belong to the Pseudanabaena cluster. AcINIAs et al. (2009) also noted a special group of complementary chromatic adaptive types, while RUDIGER et al. (2007) described the adaptive phycoerythrin capacity of a strain of Pseudanabaena from their lakes. HindÁK (2008) in his Atlas of Cyanophytes shows a photo of the species identified as $P$. galeata BöCHER with both reddish-violet and blue-green filaments.

Recently we identified a new morphotype of the genus Pseudanabaena (Cyanoprokaryota, Oscillatoriales) in Aphanizomenon flos-aquae Ralfs ex Bornet et Flahault bloom samples from large central North American water bodies, Lake Winnipeg (LWPG) and Lake of the Woods (LOW), which drains into Lake Winnipeg (Fig. 1) and isolated a strain of this morphotype from LOW in the fall of 2009. Here we describe the morphology and basic ecology, cytology and 
phylogenetic position of this new chromatic adaptive and colony forming planktonic species, proposing a new species Pseudanabaena rutilusviridis. Preliminary research has indicated that it has the ability to produce the toxin microcystin and further research is under way to assess its ability to produce taste-odour and other toxins and nitrogen-fixing capacity.

\section{Material and Methods}

Material. Pseudanabaena rutilus-viridis was initially found during routine examination of live bloom samples of the Aphanizomenon flos-aquae complex from Lake Winnipeg (2005), Lake of the Woods (2009), and more recently in Killarney Lake, Manitoba 2010. The main characters of the lakes can be seen in Table 1 .

A subsample from Lake of the Woods was sent to the Canadian Phycological Culture Collection (CPCC) at the Biology Department, University of Waterloo for isolation in late October 2009. It was isolated into CYANO growth media (Jüttner). The isolate CPCC697 was transferred and grown in $\mathrm{BG}-11$ and $\mathrm{CYANO}$ media at $10^{\circ} \mathrm{C}$ and $20^{\circ} \mathrm{C}$ in low $(3-13 \mu \mathrm{mol}$ (photons)/ $\left.\mathrm{m}^{2} . \mathrm{s}\right)$ and high light $\left(25-30 \mu \mathrm{mol}(\right.$ photons $\left.) / \mathrm{m}^{2} . \mathrm{s}\right)$. Photographs were taken of the strain CPCC under both growth conditions (Fig 2 A \& B). Width and length measurements were taken from random trichomes for over 100 cells from each treatment, and the data tested for significant differences among population means using proc UNIVARIATE and NPAR1WAY (SASC). Cell length data showed a distribution that was not significantly different from normality $(p>0.05)$ but cell width showed significant skewness and kurtosis $(p<0.01)$. Differences among means were therefore tested using non-parametric comparisons (Wilcoxon rank sum test (Mann-Whitney U test).

Microcystins and general toxicity were tested using ELISA and PPIA (expressed as total microcystin) on subsamples of culture CPCC697 at Environment Canada (EC), Burlington, Ontario.

Total chlorophyll and break down of the chlorophyll as measured using a Fluoroprobe (to be verified by HPLC) was undertaken on two subsamples (CPCC 697) at the Freshwater Institute Winnipeg, MB.

Electron microscopy. A subsample of CPCC697 was grown on agar plates at the Institute of Botany, Třeboň, Czech Republic, and filaments from these agar cultures were fixed in two fixatives:

a) osmium fixation: $1 \%(\mathrm{w} / \mathrm{v})$ osmium tetroxide in $0.7 \%(\mathrm{w} / \mathrm{v})$ veronal-acetate buffer, $\mathrm{pH} 6.5$, with traces of natrium chloride and calcium chloride, was applied for 3 hours, followed by postfixation with $0.5 \%(\mathrm{w} / \mathrm{v})$ uranyl acetate in the same buffer;

b) glutaraldehyde fixation: $3 \%(\mathrm{w} / \mathrm{v})$ glutaraldehyde in $100 \mathrm{mM}$ cacodylate buffer, $\mathrm{pH} 7.3$, was applied

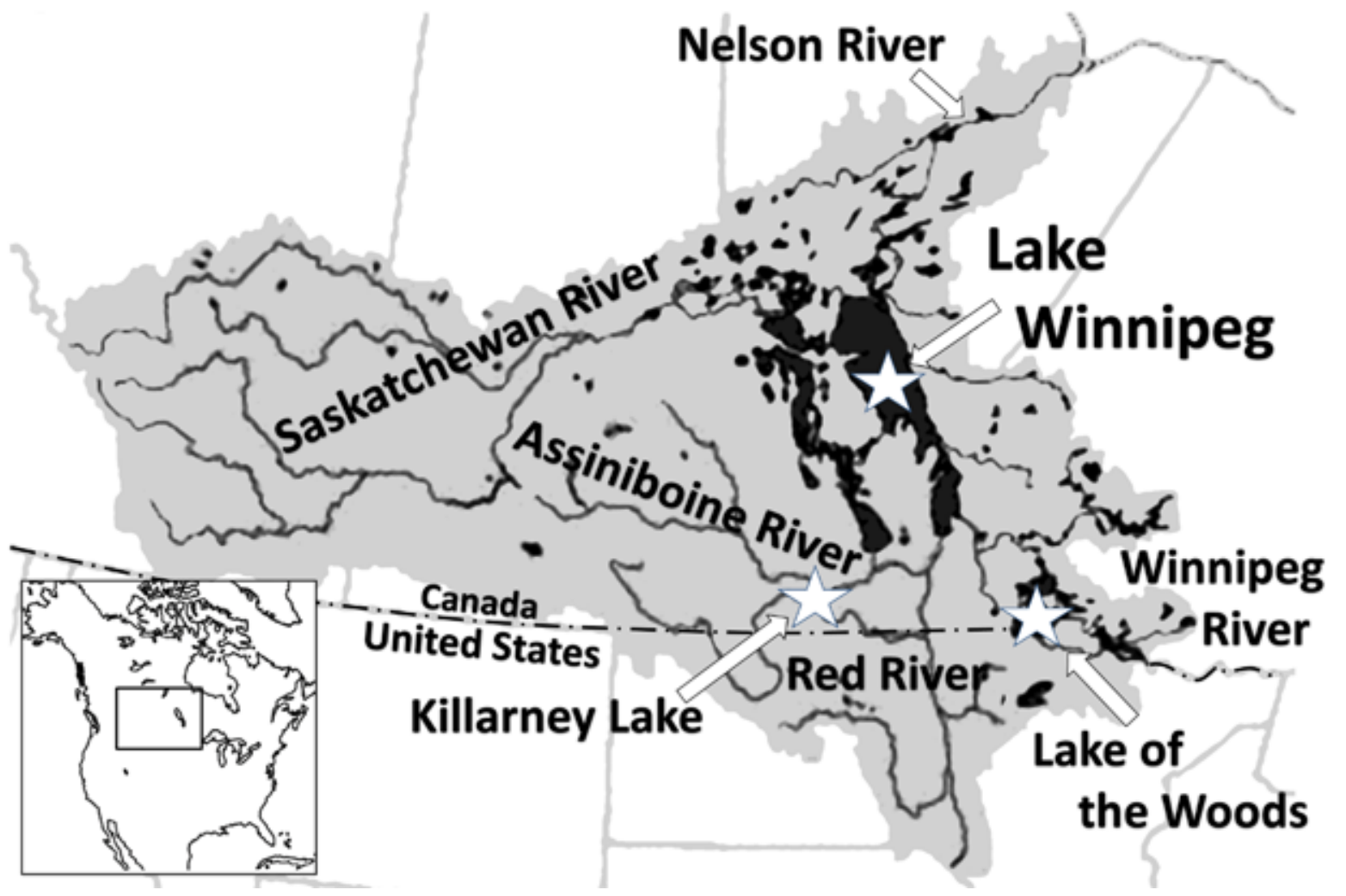

Fig. 1. Map of regions and stars on lakes indicate lake and region from where the samples were taken. 
at $4{ }^{\circ} \mathrm{C}$ over night, washed $3 \times(10 \mathrm{~min}$ each $)$ with the same buffer, followed by postfixation with $2 \%$ $(\mathrm{w} / \mathrm{v})$ osmium tetroxide in the same buffer for 2 hours.

The fixed material was washed $3 \times(10 \mathrm{~min}$ each $)$ with the fixation buffer above, instilled into $2 \%(\mathrm{w} / \mathrm{v})$ agar and dehydrated by a gradual series of ethanol baths with concentrations increasing from $30 \%$ to $100 \%$ (w/v), at 3-hour intervals. Following this, the material was infiltrated with the metacrylate LR White Hard, encapsulated and polymerized by $60{ }^{\circ} \mathrm{C}$ temperature for 2 days. Sectioning was undertaken using a Reichert-Jung ultramicrotome Ultracut E. The final sections placed on supporting grids were contrasted with $2.5 \%(\mathrm{w} / \mathrm{v})$ uranyl acetate and with the alkaline Reynolds solution $(3 \%, \mathrm{w} / \mathrm{v}$, lead nitrate with $3 \%$, w/v, Sodium citrate). The final sections were photographed at various magnifications in a digital transmission electron microscope FEI Morgagni 268D (Figs 5-6).

Genomic DNA Extraction, PCR Amplification, and Sequencing. Total genomic DNA was isolated from fresh culture material (CPCC697) at the Molecular Microbial Ecology Laboratory (IMET-UMCES) by the following method: $2 \mathrm{ml}$ of fresh culture material was washed $3 \times$ with TE buffer, centrifuged at 10,000 rpm for $10 \mathrm{~min}$ at $4{ }^{\circ} \mathrm{C}$. The supernatant was discarded, keeping the cyanobacterial pellet. This pellet was macerated for $8 \mathrm{~min}$ and boiled for $12 \mathrm{~min}$, releasing the genomic DNA. The boiled material was centrifuged at $5,000 \mathrm{rpm}$ for $10 \mathrm{~min}$, and the supernatant was used as the template for polymerase chain reaction (PCR), in 3 concentrations $(1 \mathrm{x}, 1 / 3 \times$, and $1 / 10 \times$ original conc.), to decrease the effect of other organic components.

Partial 16S rRNA was amplified by using the oligonucleotide primers CYA106F (5'-CGG ACG GGT GAG TAA CGC GTG-3') and CYA781R (5'GAC TAC AGG GGT ATC TAA TCC-3') (NüBEL et al. 1997) and the almost complete $16 \mathrm{~S}-23 \mathrm{~S}$ internal transcribed spacer (ITS) of the rRNA operon, including the tRNA $^{\text {Ala }}$ and tRNA ${ }^{\text {Ile }}$, was amplified using the primers Picocya $16 \mathrm{~S}-\mathrm{F}$ (5'-TGG ATC ACC TCC TAA CAG GG-3') and Picocyano 23S-R (5'-CCT TCA TCG CCT CTG TGT GCC-3') (CAI et al. 2010)). A $50 \mu \mathrm{l}$ reaction for each sample was performed on a $\mathrm{MJ}$ Research PYC-200 Thermo Cycler, with the following conditions: 1) $94{ }^{\circ} \mathrm{C}$ for $\left.5 \mathrm{~min}, 2\right) 94{ }^{\circ} \mathrm{C}$ for $60 \mathrm{sec}$, 3) $55{ }^{\circ} \mathrm{C}$ for $\left.60 \mathrm{sec}, 4\right) 72{ }^{\circ} \mathrm{C}$ for $\left.60 \mathrm{sec}, 5\right)$ repeat steps 2-4 for 35 cycles, 6) $72{ }^{\circ} \mathrm{C}$ for $10 \mathrm{~min}$, then 7) $4{ }^{\circ} \mathrm{C}$, indefinitely. The concentration of the amplified products was verified on a $1 \%$ agarose gel. Direct sequencing of PCR products, with primers CYA106F and Picocya 16S-F, for both the 16SrRNA gene and the ITS, respectively, were undertaken using Big Dye Terminator Chemistry and an ABI 3130 XL Genetic Analyzer (Applied Biosystems, Foster City, CA) at the BioAnalytical Services Laboratory (BASLab) of the Institute of Marine Technology, University of Maryland
Center for Environmental Sciences (IMET-UMCES).

The Basic Local Alignment Search Tool (BLAST) of the National Center for Biotechnology Information (NCBI) was utilized for locating strains/ sequences similar to our proposed new taxon. The phylogenetic analysis of $16 \mathrm{~S}$ rRNA was based on 811 sites and 46 sequences; the ITS was based on 813 sites and 41 sequences. We obtained 45 and 40 reference sequences for the 16S rRNA and ITS, respectively, from NCBI after performing BLAST and identifying similar sequences (see Supplement Table S2).

Sequences were aligned using MAFFT version 6 (KАTOH \& TоH, 2008), then manually refined considering conserved regions using SeaView version 4 (GouY et al., 2010). For construction of the phylogenetic trees, substitution models for nucleotide evolution for both the 16S rRNA and ITS was determined using jModeltest (GUINDON \& GASCUEL 2003; PosAdA 2008). Under the Bayesian Information Criterion (BIC), the GTR+gamma model was utilized for the 16S rRNA and HKY+I+gamma for the ITS. Three trees were constructed on these two markers. The software MrBayes v3.2 (RonQuist \& HuELSENBECK 2003) was used for determining Bayesian inference. For priors, we assumed no prior knowledge on the data, thus a Dirichlet $(1,1,1,1,1,1)$ prior for substitution rate parameters was estimated, in addition to, a uniform prior $(0,1)$ for the pinvar parameter. A uniform $(0$, 200) prior was set on the gamma shape parameters and for branch lengths, an unconstrained:Exponential (10) prior. Two runs of four chains (three heated and one cold) were run for $1.5 \times 10^{6}$ generations, sampling every 100 trees. In each run, the first $25 \%$ of samples were discarded as the burn-in phase. Maximum Likelihood (ML) and Maximum Parsimony (MP) analyses were conducted using MEGA 5.0 (TAMURA et al. 2011). Parsimony was run considering all sites informative and using the Close-Neighbor-Interchange algorithm. Maximum likelihood was run using the GTR+gamma model (for $16 \mathrm{~S}$ rRNA) and $\mathrm{HKY}+\mathrm{I}+$ gamma (for ITS). Statistical analyses of tree topologies were undertaken by performing bootstrap analysis with 1,000 pseudoreplicates. After comparison of different tree topologies, the Bayesian tree was prepared for publication for the $16 \mathrm{~S}$ rRNA and the ML tree was used for the 16S-23S internal transcribed unit.

The DNA sequences from both genes of Pseudanabaena rutilus-viridis CPCC 697 are deposited in the NCBI GenBank under the accession numbers JN641732 and JN641733.

\section{Results and Discussion}

Ecology and morphology. This new species of Pseudanabaena has been found in Lake of the Woods, Lake Winnipeg and more recently in 
Table 1. Summary values of major physical and chemical parameters for study lakes.

\begin{tabular}{|c|c|c|c|}
\hline Parameters & Lake of the Woods & Lake Winnipeg & Killarney Lake \\
\hline $\begin{array}{l}\text { Coordinates (degrees; } \\
\text { longitude, latitude) }\end{array}$ & $49-50^{\circ} \mathrm{N} ; 95^{\circ} \mathrm{W}$ & $\begin{array}{l}96^{\circ} 20^{\prime}-99^{\circ} 20^{\prime} \mathrm{W} . \\
50^{\circ} 20^{\prime}-53^{\circ} 51^{\prime} \mathrm{N} .\end{array}$ & $49^{\circ} 11^{\prime} \mathrm{N} ; 98^{\circ} 42^{\prime} \mathrm{W}^{6}$ \\
\hline $\begin{array}{l}\text { Surface Area }\left(\mathrm{km}^{2}\right) \text { Who- } \\
\text { le Lake }\end{array}$ & $3,630^{2}$ & $23,750^{3}$ & $1.64^{6}$ \\
\hline $\begin{array}{l}\text { Max depth } Z_{\text {max }}(\mathrm{m}) \\
\text { Whole Lake }\end{array}$ & $54.3^{2}$ & $36^{7}$ & $6^{6}$ \\
\hline $\begin{array}{l}\text { Mean depth } Z_{\mathrm{m}}(\mathrm{m}) \\
\text { Whole Lake }\end{array}$ & $6.3^{2}$ & $12.0^{3}$ & \\
\hline Mixing regime & Dimictic/Polymictic & $\begin{array}{l}\text { Polymictic/weakly stra- } \\
\text { tified }\end{array}$ & Polymictic \\
\hline $\begin{array}{l}\text { Residence time (yr) } \\
\text { Whole Lake }\end{array}$ & $1.7^{2}$ & $4.4^{3}$ & Indefinite (no out flow) \\
\hline Secchi depth (m) & $1.2-3.3^{8}$ & $0.8-1.9^{4}$ & $0.8-2.85^{6}$ \\
\hline $\mathrm{pH}$ & $8.0^{8}$ & $8.3^{11}$ & $8.2^{6}$ \\
\hline $\begin{array}{l}\text { Conductivity ( } \mu \text { mhos. } \\
\mathrm{cm}^{-1} \text { ) }\end{array}$ & $82-125^{8}$ & $200-318^{11}$ & $753^{6}$ \\
\hline $\begin{array}{l}\text { Avg. summer epilimnetic } \\
\text { temperature }\left({ }^{\circ} \mathrm{C}\right)\end{array}$ & $19-20^{8}$ & $20-25^{4}$ & 20-25 (estimate) \\
\hline $\operatorname{DOC}\left(\mathrm{mg} \cdot \cdot^{-1}\right)$ & $9.7^{8}$ & $7.3-10.2$ & \\
\hline $\operatorname{DIC}\left(\mathrm{mg} . \mathrm{l}^{-1}\right)$ & $9.7^{8}$ & $17.4-26.4$ & $176-206^{6}$ \\
\hline Alkalinity (mg. $\left.\mathrm{l}^{-1}\right)$ & $38-56^{9}$ & $43-178$ & 195 \\
\hline $\mathrm{TN}\left(\mu \mathrm{g} .1^{-1}\right)$ & $414-475^{8}$ & $459-823^{11}$ & $0.750-1.5^{6 \mathrm{a}}($ as TKN $)$ \\
\hline $\mathrm{TP}\left(\mu \mathrm{g} . \mathrm{l}^{-1}\right)$ & $19-25^{8}$ & $25-126^{11}$ & $\begin{array}{l}30-275^{6}, 12-516^{13} \\
35-185^{6 a}\end{array}$ \\
\hline $\begin{array}{l}\text { Mean chla }\left(\mu \mathrm{g} .1^{-1}\right) \text { Who- } \\
\text { le Lake }\end{array}$ & $4.1-8.7^{8}$ & $3.3-9.7^{11}$ & $11-32^{6}, .7-94^{13}$ \\
\hline $\begin{array}{l}\text { Algal bloom biomass } \\
\text { (range; } \mu \text { g. } .^{-1} \text { ) }\end{array}$ & $5000-45000^{10}$ & $7000-87000^{10}$ & $7500-100000^{10}$ \\
\hline $\begin{array}{l}\text { Late summer cyanobacte- } \\
\text { ria bloom species }\end{array}$ & $\begin{array}{l}\text { Aphanizomenon flos- } \\
\text { aquae complex (several } \\
\text { morphotypes) }\end{array}$ & $\begin{array}{l}\text { Aphanizomenon flos- } \\
\text { aquae complex (several } \\
\text { morphotypes) }\end{array}$ & $\begin{array}{l}\text { Aphanizomenon } \\
\text { flos-aquae v. flos-aquae } \\
\text { complex }\end{array}$ \\
\hline
\end{tabular}

${ }^{1}$ Yang \& Teller (2005); ${ }^{2}$ Zhang et al. (in prep.); ${ }^{3}$ Zhang \& Rao (2010); ${ }^{4}$ Salki (2007); ${ }^{5}$ McCullough et al. (in press.); ${ }^{6}$ Richmond (1997); ${ }^{7}$ Brunskill et al. (1980); ${ }^{8}$ Watson, Pascoe et al. (unpublished, 2008-09); ${ }^{9}$ Lake of the Woods - Status Report (2006 wq-lar39-0002); ${ }^{10}$ Kling (unpublished); ${ }^{11}$ McCullough (unpublished); ${ }^{12}$ Goldborough unpublished (1991); ${ }^{13}$ Manitoba Conservation Water Quality Data unpublished; blank = no data found

Killarney Lake (Fig. 1). All three lakes situated in the very large drainage basin of Lake Winnipeg are shallow prairie or partially prairie lakes dominated in the late summer and fall with cyanobacterial blooms consisting of one - several morphotypes of the Aphanizomenon flos-aquae complex. Lake
Winnipeg and Lake of the Woods are lakes with shallow areas where the turbid nutrient rich, high $\mathrm{pH}$ and conductivity prairie waters flow into regions of clear water with low nutrient, low $\mathrm{pH}$ and low turbidity water from the Canadian Shield. Killarney Lake, a shallow (6 meters maximum 
depth) turbid eutrophic prairie riverine lake also with periods or areas of very low visibility, has generally higher conductivity and alkalinity. A range of chemical and physical parameters for the three localities is given in Table 1. This table has been included to give the readers a very general impression of the types of lakes with in which this species occurs. The habitat for this species covers a wide range of both physical and chemical conditions since the two larger lakes both border two very distinct geological regions.

The sample from which this species was isolated, was collect, by J. Toogood from Lake of the Woods, Whyle Point in September 2009. This was a sample dominated by Aphanizomenon flos-aquae complex, which was accompanied in the background levels of Pseudanabaena rutilusviridis, found either in small flakes or entwined in the loose bundles of Aphanizomenon. This sample was sent to J. Acreman at the University of Waterloo Canadian Phycological Culture Centre for isolation of cyanobacteria in particular Aphanizomenon morphotypes. However, by November 2009 a nice population of a P. rutilusviridis single trichomes and flakes was growing in some of the cultures. Further isolation and experimentation at low and high light yielded information on its ability to chromatic adapt (Supplement Fig. S1). Figures 2 A-E show the variation in morphology and pigmentation of trichomes under low (3-13 $\mu \mathrm{mol}$ (photons)/ $\left.\mathrm{m}^{2} . \mathrm{s}\right)$ and high light $\left(25-30 \mu \mathrm{mol}(\right.$ photons $\left.) / \mathrm{m}^{2} . \mathrm{s}\right)$ at $10{ }^{\circ} \mathrm{C}$ and $20^{\circ} \mathrm{C}$ resp. Light also affected the pigmentation and the red cultures grown in low light after exposure to higher light began to shift their dominant pigment from reddish to green within 4-5 days of exposure to the new condition Cells appeared much healthier and less fragmented in the low temperature low light conditions (Fig. 2E) where the filaments under low light were found in greater frequency in flakes (Fig. 2F) while those in the high light even at the low temperature were more fragmented and shorter (Fig. 2D). Figure 3 shows a graph of measurements from cultures grown at $10{ }^{\circ} \mathrm{C}$ under high and low light. There is some slight degree of the variation in cell dimensions between the culture conditions with a small but significant difference in width but not in length (Figs 3a, b, S3).

Under natural conditions $P$. rutilus-viridis is primarily found in single trichomes except in circumstances where filaments sometimes entwine themselves between the flake filaments

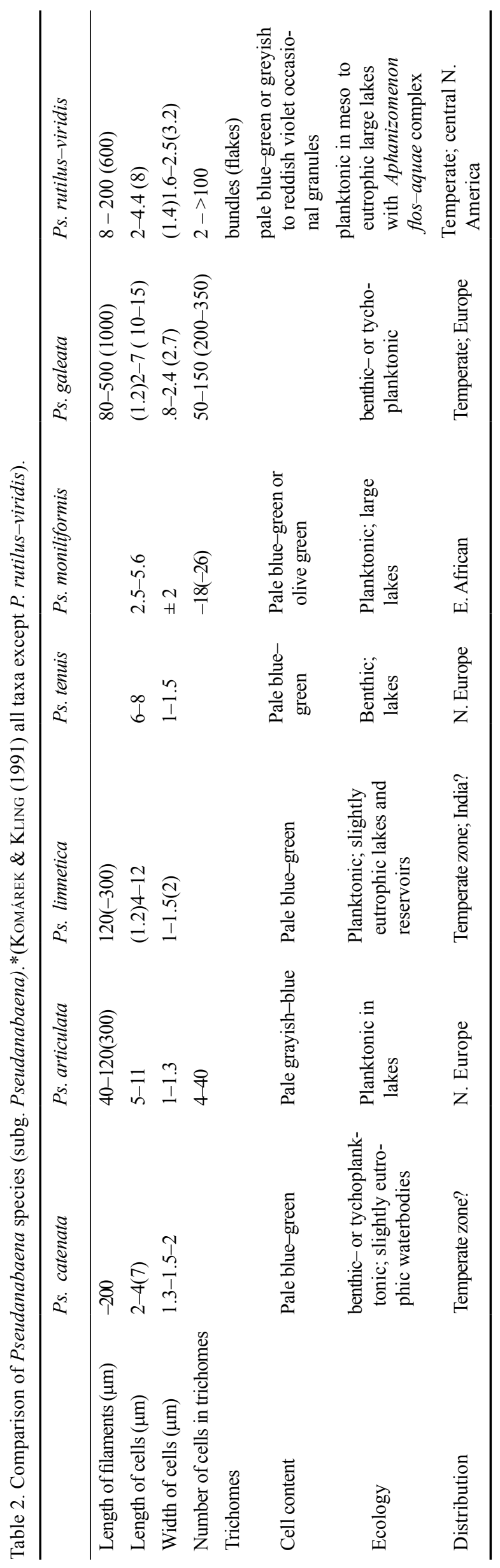



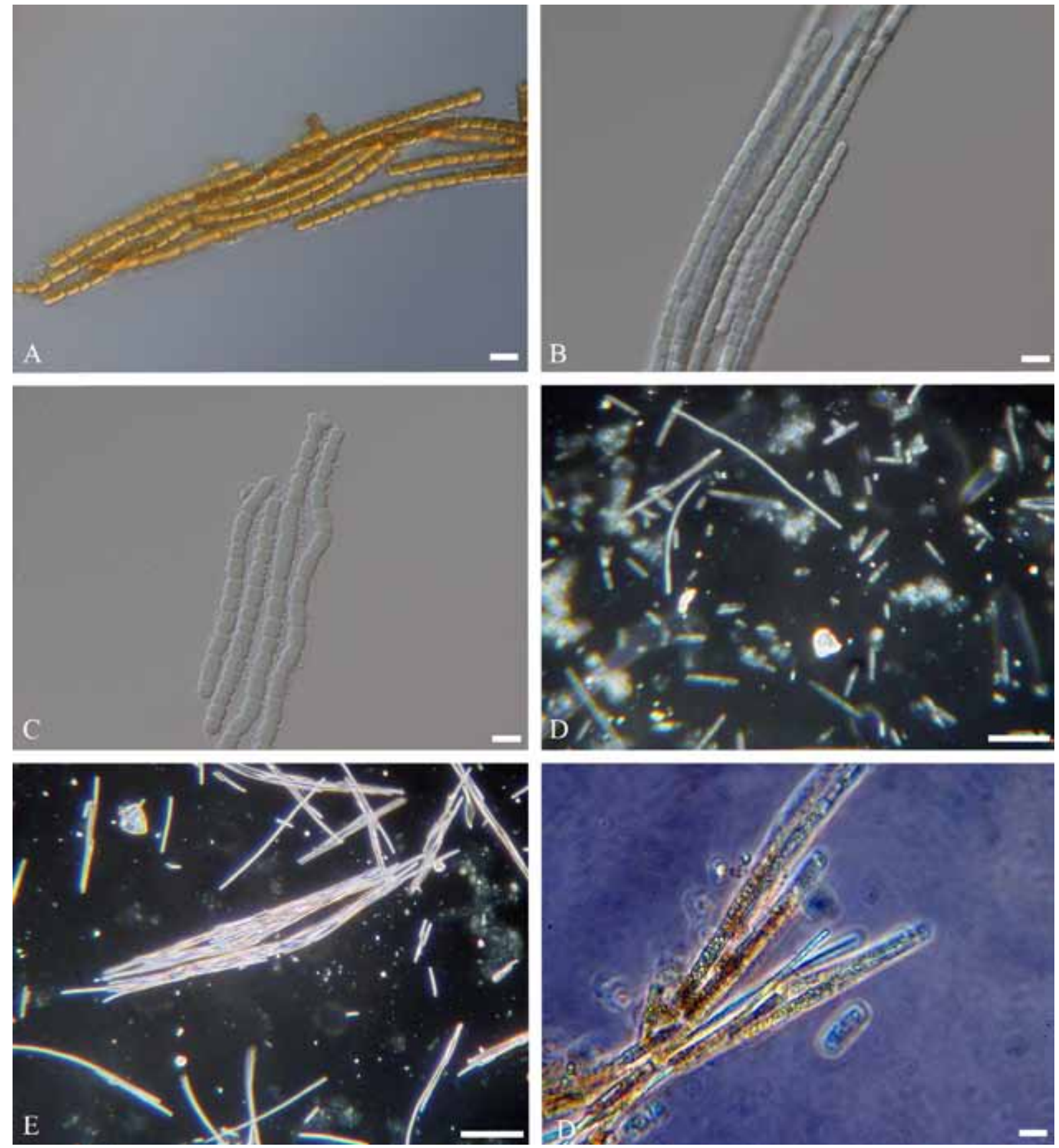

Fig. 2. (A) filaments and cell morphology in P. rutilus-viridis cultures at $10^{\circ} \mathrm{C}$ and low light. In color photo has a reddish coloration (See Supplementary Fig. 1); (B, C) filaments which were cultured in high light and $10^{\circ} \mathrm{C}$; (D) morphology of $P$. rutilus-viridis in culture grown at $10{ }^{\circ} \mathrm{C}$ in high light showing a lower frequency of flakes and greater fragmentation, and shorter length of filaments; (E) morphology of P. rutilus-viridis in culture grown at $10{ }^{\circ} \mathrm{C}$ in low light showing high frequency of flake formation and reddish purple pigmentation( in colored photo); (F) an example of $P$. rutilus-viridis single filaments and filaments entwined in Aphanizomenon flos-aquae complex colonies in sample from Lake of the Woods, Lily Pad Bay, June 2010. Scale bar $10 \mu \mathrm{m}(\mathrm{A}-\mathrm{C}, \mathrm{F}), 50 \mu \mathrm{m}(\mathrm{D}, \mathrm{E})$.

of (Fig. 2F) morphotypes of the Aphanizomenon flos-aquae complex, which often come together in a mixed population in the regions where the turbid nutrient-rich water enters the more lightreplete regions of the north basins of both Lake Winnipeg and Lake of the Woods. The P. rutilusviridis flake formation seems to occur primarily when the Aphanizomenon population is beginning to collapse or in a state of collapse. This became more apparent when a sample of a good healthy population was brought to the lab and kept for several days in the refrigerator. An interesting phenomenon was observed in that recent bloom sample of Aphanizomenon flos-aquae complex 

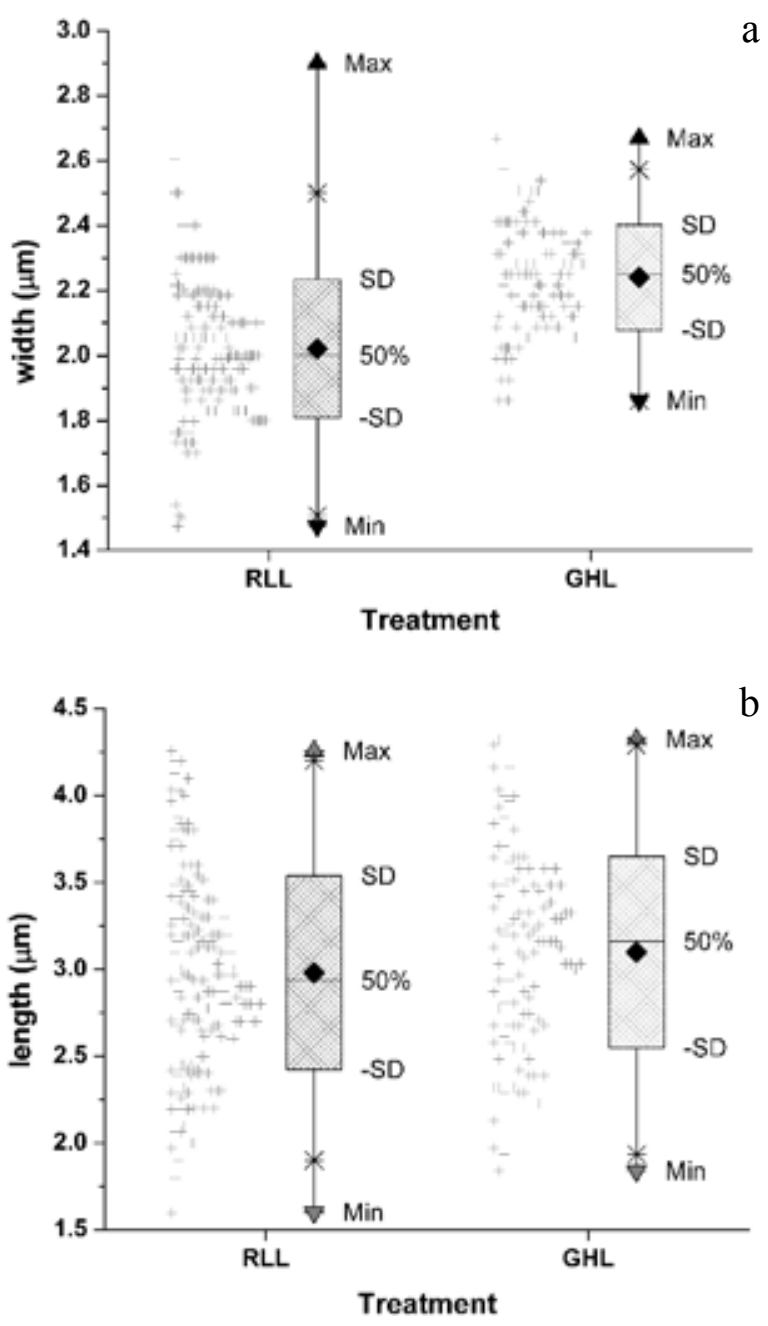

Fig. 3. Box and whisker plots of Pseudanabaena rutilusviridis cell width (3a) and length ( $3 b$ ) measurement statistics for red phenotype, grown under low light (RLL) and green phenotype, grown under high light (GHL). Plots show data (crosses), offset to the left. Legend: mean (diamond), median (50\%), standard deviation (SD), 1-99\% percentiles (star), minima and maxima (black triangles).

taken from Lake Winnipeg August 9, 2010. In the original preserved sample Pseudanabaena rutilus-viridis existed either as separate single filaments with a few flakes in the background of the Aphanizomenon bloom or entwined within the Aphanizomenon flakes. Re-examination of this sample following 3 weeks in the refrigerator $\left(5{ }^{\circ} \mathrm{C}\right)$ showed healthy Pseudanabaena rutilusviridis in the sample and primarily forming flakes. The flakes and still some single trichomes dominated the sample along with amoeba and phagotrophic flagellates and the Aphanizomenon had disappeared except for akinetes and heterocytes. It seems from this observation that the Pseudanabaena may potentially have some heterotrophic capacity and is not harmed by the a predators which consumed Aphanizomenon. This of course needs further research and is beyond the scope of this paper. Re-examination of old bloom samples also showed the presence of this species accompanying blooms dominated by Aphanizomenon flos-aquae complex in Lake Winnipeg. It is not new to the lakes but was not recognized as a unique or new species until this present study.

Comparisons of cell morphology, filament length and structure, etc., are presented in Table 2. The dimensions of P. rutilus-viridis overlap with several other Pseudanabaena species. However, it is unique in its association with the Aphanizomenon flos-aquae complex, ecology, ability for chromatic adaptation and the formation of flakes. Red pigments (PE) predominated under low light and is quite noticeable in the culture vials (Supplement Fig. S1). Fluoroprobe analysis of older cultures showed the red pigments indicating phycoerythrin were high and variable. The ratios of pigments present under the different conditions still need to be confirmed using HPLC and/or the absorption spectra (400-700nm) of culture under different light regimes (ie white, green and red light) to confirm the group of CCA defined by Kenoe \& Gutu (2006). The initial screening for microcystin production indicated below detection using ELISA and low-level toxicity using PPIA screening. This indicates the possibility for potential toxins, and needs further research for confirmation.

\section{Pseudanabaena rutilus-viridis KLING,}

Laughinghouse et KomáreK sp. nov. (Figs 2, 4) Diagnosis: trichoma plus minusve recta vel paucim curvata, libere natantia, solitaria, mobilia (tremula

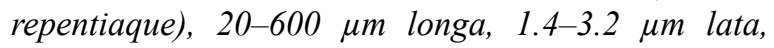
sine muco vel vagina mucilaginosa, interdum ad fasciculos parvos coniuncta. Trichoma cylindracea, ad dissepimenta constricta. Cellulae isodiametricae vel leviter longior (1-2×) quam latae, cylindricae, barriliformes ad ovales, apice rotundatae vel rotundato-acutae, contentu homogeneo, pallide aerugineo vel rubescente, interdum cum granulis solitariis prope dissepimenta, 2-8 $\mu \mathrm{m}$ longae, 1.4-3.2 $\mu \mathrm{m}$ latae. Divisio cellularum perpendiculariter; trichoma phragmentatione dividuntur. Heterocytae, akineta vel ramificatio carentes. - Habitatio: Planktice in lacubus mesotrophicis ad eutrophicis in Canada meridionali. Typus: Exsiccatum No 2335 in herbario BRNM/HY depositum et CANA 84235 in herbario Ottawa; cultura typica No CPCC 697 in collection CPCC (University of Waterloo) deposita; icona typica: figurae nostrae 2 et 4 . 

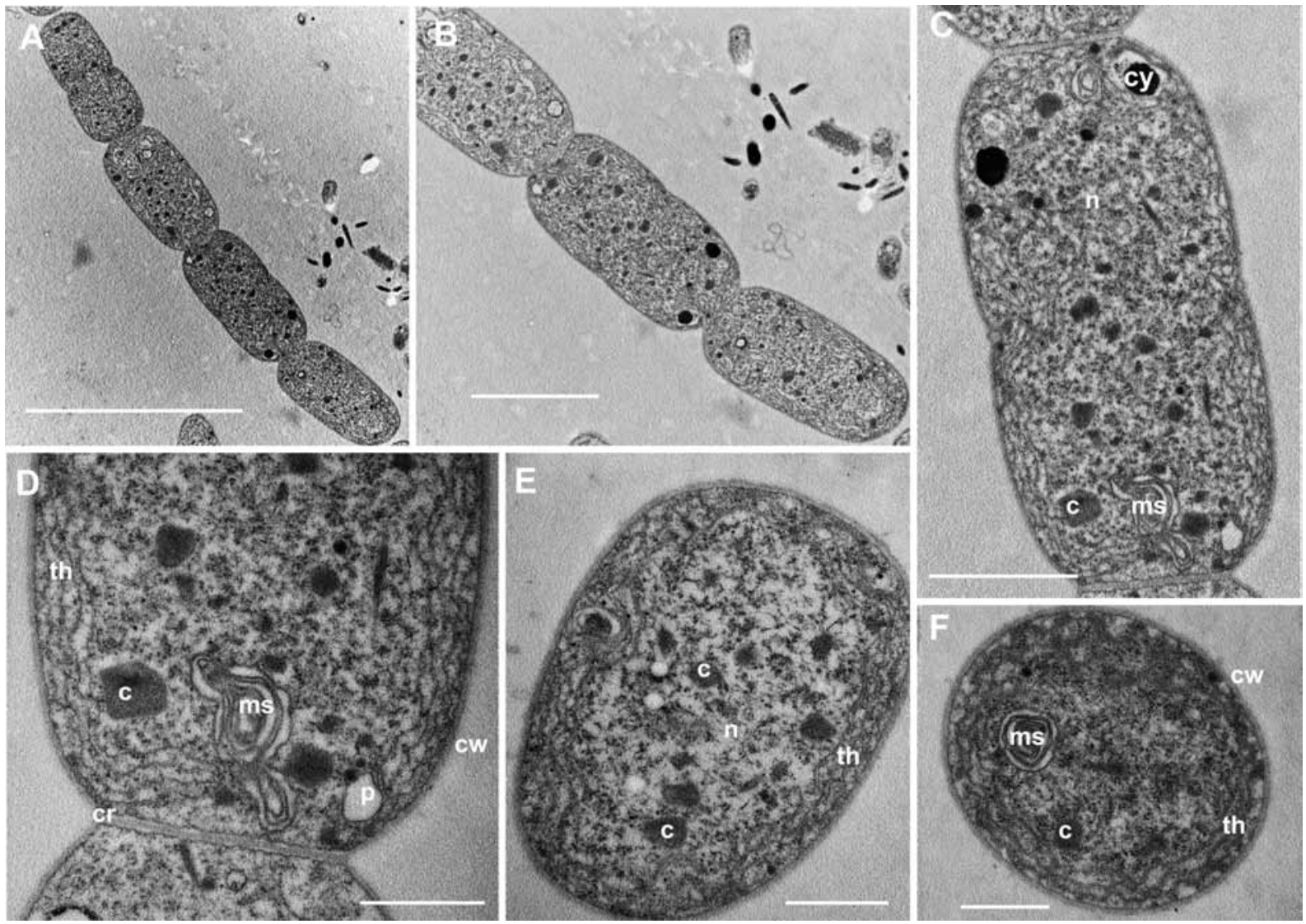

Fig. 4. Morphology and ultrastructure of Pseudanabaena rutilus-viridis . Thin sections showing general trichome or filament structure from ultrathin sections (TEM): (A-B) general view of longitudinal section of a cell, (C-D) detail of vegetative cells, (E-F) cross and oblique sections. Explanations: (cy) cyanophycin granules, (n) nucleoid, (c) carboxysomes, (ms) specific membrane system, (th) thyalokoids, (cr) crosswalls, (cw) cell wall, (p) polyphosphate bodies. Scale bars on each micrograph.

Description: trichomes solitary, planktonic, motile (trembling and creeping), $<20->200(600)$ $\mu \mathrm{m}$ long and usually (1.4)1.6-2.5 (3.2) $\mu \mathrm{m}$ wide, without mucilage or sheath, sometimes arranged in small flake-like colonies. Cells isodiametric or slightly longer than wide $(1-2 \times)$, cylindrical, barrel shaped to oval with rounded ends or bluntly pointed, pale homogenous, reddish violet or blue-green contents (chromatic adaptive), constricted at the cross walls and sometimes with a granule (aerotopes?) at the cross-walls, 2-4.4 (up to 8) $\mu \mathrm{m}$ long $\times(1.4) 1.6-2.5(3.2) \mu \mathrm{m}$ wide. Cell division perpendicular, trichomes separate by cell disintegration, necridia or fragmentation. Heterocytes not known.

Type locality: large Central Canadian Lakes Type strain and type material: Canadian Phycological Culture Collection CPCC 697 University of Waterloo, Waterloo Ontario Deposited in Canadian Museum of Nature, Ottawa: Assession number CANA 84325

Isotype: GenBank Accession Numbers: JN641732 and JN641733.
Ultrastructure. The ultrastructure (Figs 4-5) corresponds in principle to other Pseudanabaena studies (Whitton \& Peat 1969; Bourrelly \& Couté 1975; Guglielmi \& Cohen-Bazire 1984; CHANG et al. 1985), but there are some specific differences. The thylakoids (th) are arranged more or less in parietal fascicles but more undulating, than has been found in other species. The nucleoplasma (n) is located in the centre of cells. The cell wall (cw) and cross walls (cr) are simple, similar to other Pseudanabaena-species, without prominent mucilaginous envelopes or sheaths. The cells show numerous carboxysomes (c), solitary cyanophycin (cy) and /or polyphosphate (p) granules. Polar gas vesicles were lacking, and were never observed. The thylakoids were occasionally enlarged in cells from older cultures (Fig. 5). More unique and interesting were the groups of membrane systems (ms) found situated near the poles of several cells (Fig. 5).

Phylogenetic Analysis. The three phylograms (Bayesian, ML, and MP) for each genetic marker 

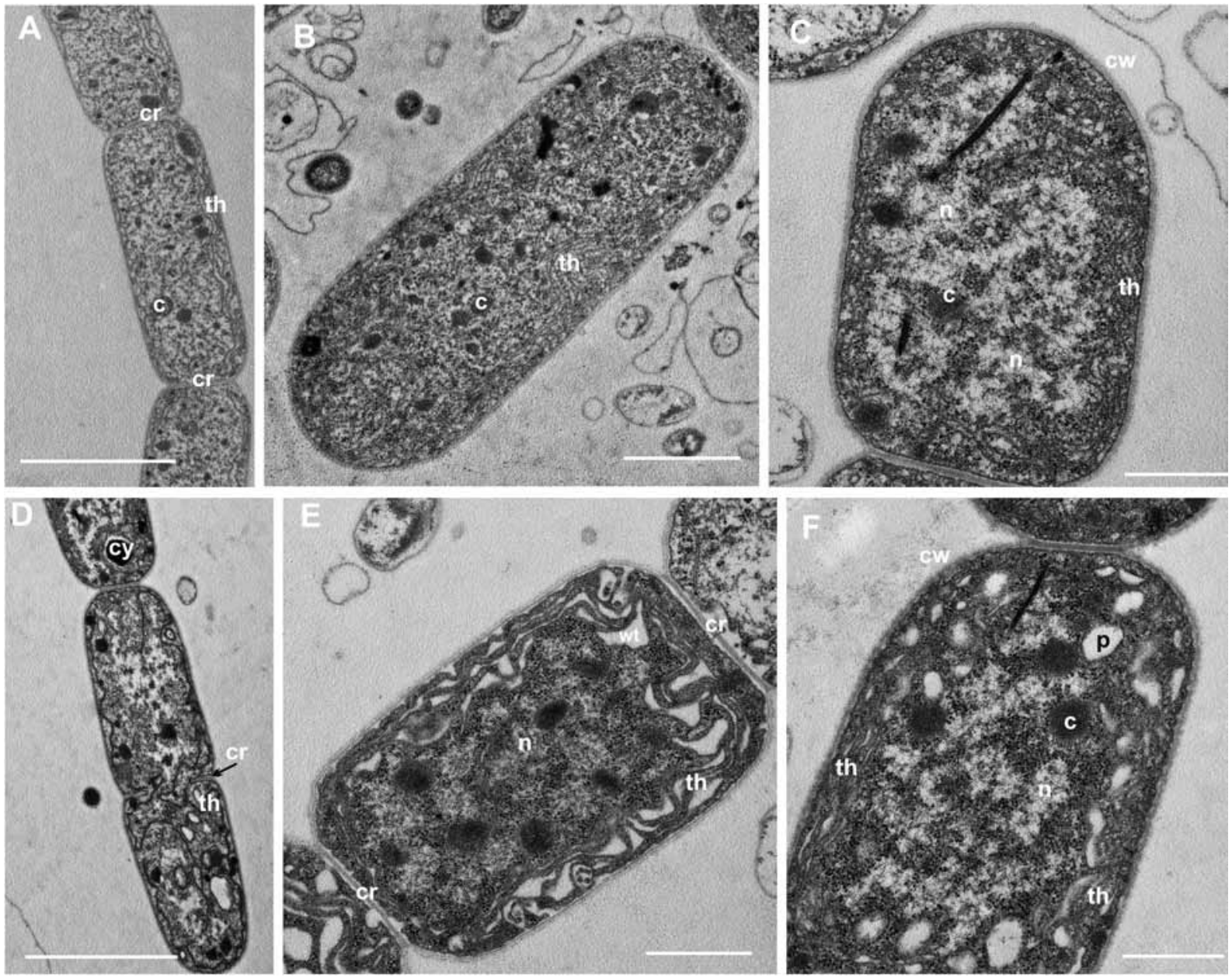

Fig. 5. Fine sections through cells of Pseudanabaena rutilus-viridis. In several cells occur widened thylakoids (wt). Explanations as in Fig. 5. Scale bars in micrographs.

were similar. We show the Bayesian phylogram for the 16S rRNA gene (Fig. 6) and the ML phylogram for the ITS region (Fig.7), with the bootstrap support values and Bayesian posterior probability on the respective nodes.

Pseudanabaena rutilus-viridis falls within the clade of the genus Pseudanabaena in all analyses conducted using both genetic markers, with high support values. It is also a novel branch in both the 16S rRNA and ITS phylograms. The highest similarity for $16 \mathrm{~S}$ rRNA was to Pseudanabaena sp. ABRG5-3 (96\% identity, $87 \%$ coverage) and Pseudanabaena sp. dqh15 (97\% identity, $87 \%$ coverage); for ITS, it was Limnothrix redekei CCAP 1443/1 (91\% identity, $67 \%$ coverage) and Pseudanabena minima GSEPSE20-05C ( $87 \%$ identity, $72 \%$ coverage).

Our analyses found that within the Pseudanabaena clade, there were some peculiar taxa. Anabaena spiroides NIES-78 was found to cluster together with Pseudananabena. Looking through GenBank, we noticed that this taxa had also been identified as Anabaena solitaria NIES78 thus giving us the confidence to state that the same strain could potentially be forming straight filaments, however this still does not explain how a member of Nostocales is clustering with Pseudanabaena. Using BLAST, we searched the NCBI database for the sequences that were most closely related and its closest hits were Anabaena solitaria NIES-78, and other Pseudanabaena sp. strains, several which are used in this study. This led us to believe to the erroneous identification of this strain. We used this same hypothesis to test the strains of Limnothrix, Oscillatoria, and Arthronema, and came to the same conclusion. This demonstrates the importance of the correct identification of strains deposited in GenBank (and the use of binomial names), to be able to study the occurrence of polyphyletic genera or just trying to understand misidentifications carried out by previous works. 


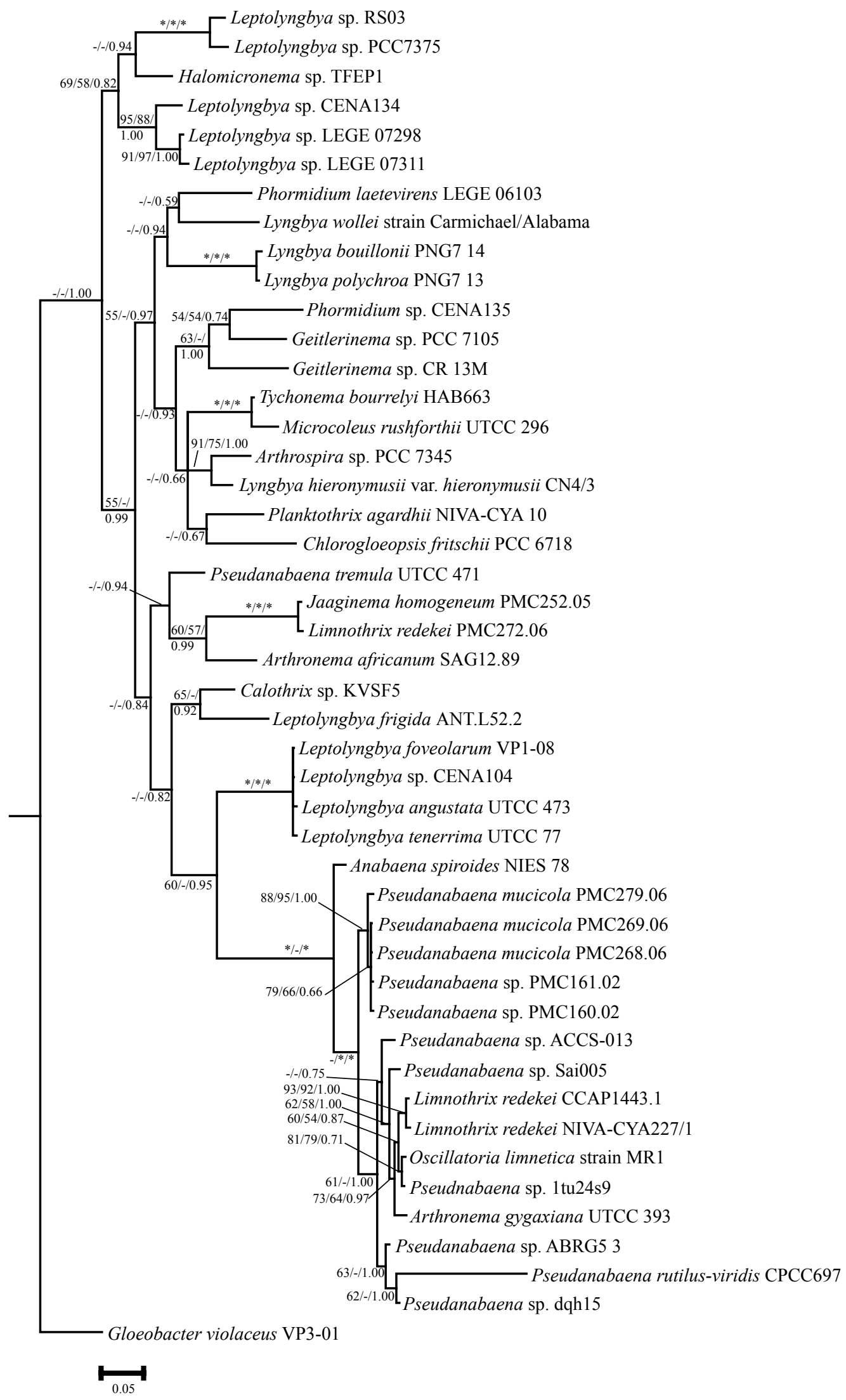

Fig. 6. (16S rRNA) Bayesian phylogram calculated from 46 taxa using the $16 \mathrm{~S}$ rRNA gene marker. Node support is indicated as ML/MP bootstrap support values/Bayesian posterior probabilities. An */*/* means $100 \% / 100 \% / 1.00$, a - means less than 0.50 or $50 \%$ support. 


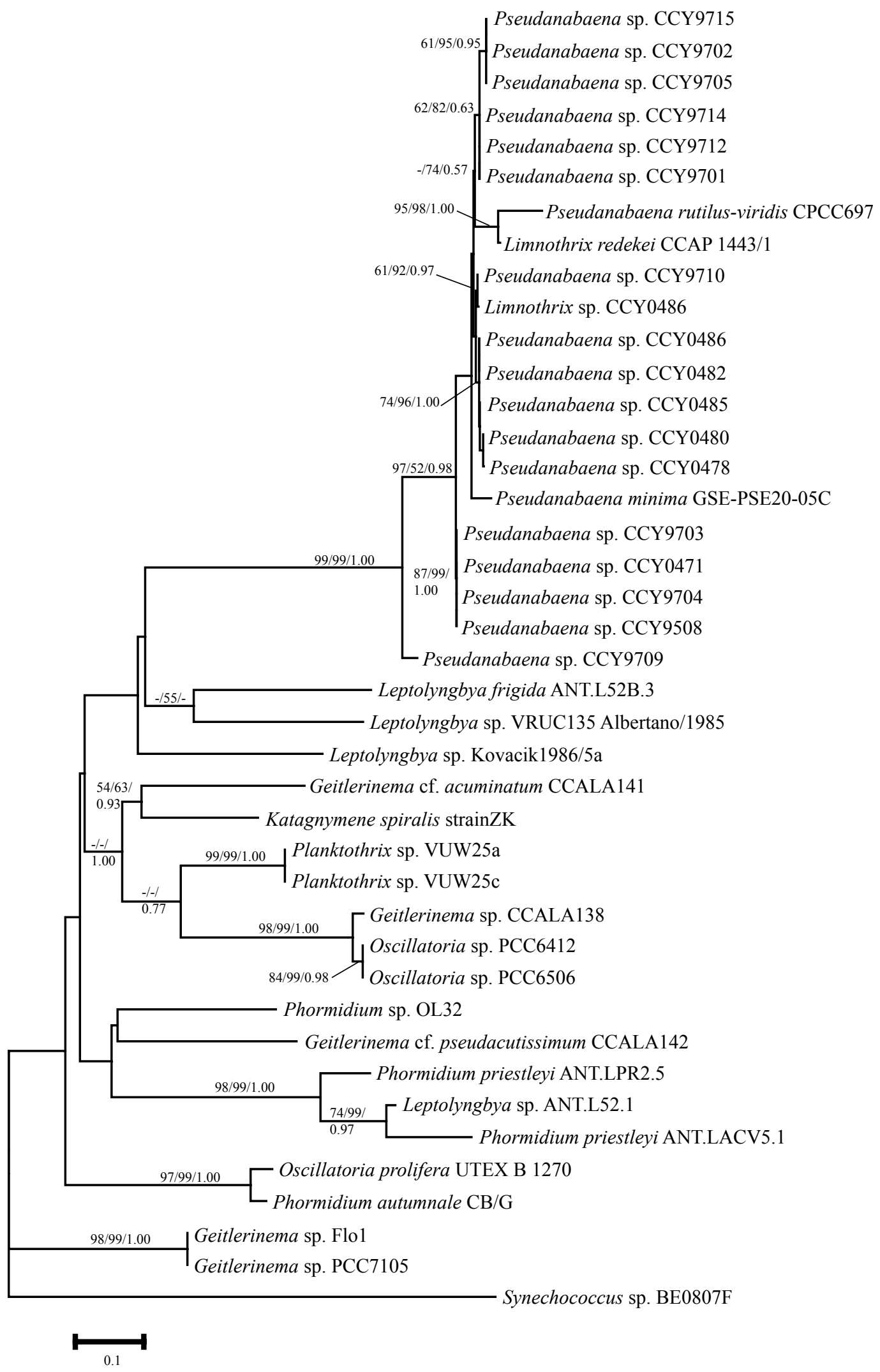

Fig. 7. (ITS) ML phylogram calculated from 41 taxa using the $16 \mathrm{~S}-23 \mathrm{~S}$ rRNA internal transcribed spacer region. Node support is indicated as ML/MP bootstrap support values/Bayesian posterior probabilities. An */*/* means $100 \% / 100 \% / 1.00$, a - means less than 0.50 or $50 \%$ support. 
Analyzing the ITS phylogram, we notice that P. rutilus-viridis is most closely related to Limnothrix redekei CCAP 1443/1 with high support. This species was probably identified incorrectly (ZWART et al. 2005), and is a species of Pseudanabaena, since we analyzed the photograph presented by them in their paper and it resembles a Pseudanabaena more than a Limnothrix.

In summary, this paper gives a morphological (including ultrastructure) description, phylogenetic placement and ecology of the new $P$. rutilus-viridis sp. nova documenting its ability to exist in the plankton in either solitary filaments or flake-like colony formation in low back ground (usually $\sim 1 \%$ by biomass) levels among the blooms of flake forming Aphanizomenon of the Aphanizomenon flos-aquae complex. Some simple tests indicated that it has chromatic adaptive capacity. Cell dimensions, filament length, colony formation and pigment composition appear to be highly related to light and temperature conditions. Screening for microcystin production indicated below detection using ELISA and low-level toxicity using PPIA screening. Phycoerythrin (red pigment) content appears to be variable depending on the light regime. Initial taste-odour screen appears to be negative. Some observations have generated the hypothesis that the species may have some heterotrophic capacity, which would enable it to survive and form flakes in cold dark conditions following the collapse of an Aphanizomenon bloom.

According to the cytological studies, $P$. rutilus-viridis fits nicely with other members of the genus Pseudanabaena with unique membrane system present at the poles of some cells. Phylogenetically Pseudanabaena rutilus-viridis falls within the clade of the genus Pseudanabaena in all analyses conducted using both genetic markers, with high support values. It is also a novel branch in both the 16S rRNA and ITS phylograms. The ITS phylogram showed it related most closely the culture identified in ZWART et al 2005 as Limnothrix redekei CCAP 1443/1 which appears to have likely been misidentified.

Further research is required for details on the geographic distribution, genetic sequencing of other markers, detailed pigment analysis, taste-odour products, toxin types and $\mathrm{N}$ fixation and heterotrophic capacity. Some of this work is currently underway.

\section{Acknowledgements}

We would like to thank Jeannie Toogood for collecting crucial Lake of the Woods 2009/2010 samples, Heather Roshon, CPCC, U of Waterloo for culturing, Diane Orhiel and Manitoba Conservation for Killarney Lake Sample 2010, Gordon Goldborough, Environmental Sciences, University of Manitoba for early 1992 Killarney Lake Data, Michael Stainton, Fisheries and Oceans Canada, Chemistry Department, Freshwater Institute, Winnipeg for fluoroprob analysis and chemistry, Zheng Liu for assistance in the molecular lab, Greg McCullough for maps and physical chemical data and Sharon Ryland for technical assistance, Rong $\mathrm{Li}$, Environment Canada, Burlington for toxin analysis, Environment Canada for Lake Winnipeg and Lake of the Woods sample collection and their continued support of algal research. The study was supported also by AV0Z60050516 (J. Komárek).

\section{References}

Acinias, S.G.; Haverkamp, T.H.; Huisman, J \& Stal, L.J. (2009): Phenotypic and genetic diversification of Pseudanabaena spp. (Cyanobacteria). - Intern. Soc. Microb. Ecol. 3: 31-46.

Anagnostidis, K. \& KomÁreK, J. (1988): Modern approach to the classification of cyanobacteria 3. Oscillatoriales. - Algological Studies 50/53: 327-472.

Bourrelly, P. \& Couté, A. (1975):_Infrastructure d'une Cyanophycee: Pseudanabaena galeata Böcher. Protistologica n, 187-194.

Brunskill, G.J.; Elliot, S. M. \& Campbell, P. (1980): Morphometry, hydrology, and watershed data pertinent to the limnology of Lake Winnipeg. - Can. Rep. Fish. Aquat. Sci. No. 1556. - 32 pp., Department of Fisheries and Oceans, Winnipeg Manitoba.

Cai, H.; Wang, K.; Huang, S.; Jiao, N. \& Chen, F. (2010): Distinct Patterns of Picocyanobacterial Communities in Winter and Summer in the Chesapeake Bay. Appl. Environm. Microbiol. 76: 2955-2960.

Chang, T.P.; Koest, H.P. \& Wanner, G. (1985): Critical observations on some Pseudanabaena species. Arch. Hydrobiol. (Suppl. 71) 1/2: 149-155.

Guglielmi, G. \& Cohen-BAZIRE, G. (1984):Etude taxonomique d'un genre de cyanobacteria Oscillatoriacée: le genre Pseudanabaena Lauterborn. I. Etude ultrastructurale. - Protistologica 20: 377-391.

Guindon, S. \& Gascuel, O. (2003): A simple, fast and accurate method to estimate large phylogenies by maximum-likelihood. - System. Biol. 52: 696-704.

Gouy, M.; Guindon, S. \& Gascuel, O. (2010): Seaview version 4: a multiplatform graphical user interface for sequence alignment and phylogenetic tree building. Mol. Biol. Evol. 27: 221-224.

HindÁk, F. (2008): Atlas of Cyanobacteria. - 253 pp., Publishing House of the Slovak Academy of Sciences, Bratislava.

Катон, K. \& Тон, H. (2008): Recent developments in the MAFFT multiple sequence alignment program. Brief Bioinform 9: 286-298.

Kehoe, D.M \& Gutu, A. (2006): Responding to color: the 
regulation of complementary

Chromatic adaptation. - Annual Review of Plant Biology 57: 127-150.

Kling, H.J.; Stainton, M.; McCullough G.; Findlay, D.L. \& Watson, S. (2009): Eutrophication, algal microfossils and Cyanobacteria in Canadian Lakes. - IAGLR Toronto Presentation.

KomÁreK, J. (2003): Planktic oscillatorialean cyanoprokaryotes (short review according to combined phenotype and molecular aspects). Hydrobiologia 502: 367-382.

KomÁReK J. \& ANAGNostidis, K. (2005): Cyanoproka-ryota -2. Teil/ 2nd Part: Oscillatoriales. - In: BÜDEL B.; Krienitz L.; Gärtner G. \& Schagerl M. (eds), Süsswasserflora von Mitteleuropa 19/2. - 759 pp., Elsevier/Spektrum, Heidelberg.

KoMÁReK, J. \& KLING, H.J. (1991): Variation in six planktonic cyanophyte genera in Lake Victoria (East Africa). Algological Studies 61: 21-45.

Lake of the Woods - Status Report (2006): wq-lar39-0002.

McCullough, G. (2005): Surface water temperature and break-up and freeze-up of the ice cover on Lake Winnipeg. - Report prepared for Fisheries and Oceans Canada for submission to Natural Resources Canada Climate Change Action Fund.

McCullough, G.; Page, S.; Hesslein, R.; Stainton, M.P.; KLING, H.J. \& BARBER, D. (in press): Hydrological forcing of a recent trophic surge in Lake Winnipeg. - J. Great Lakes Res.

Mellors, T. (2010): Holocene paleohydrology from Lake of the Woods and Shoal Lake cores using ostracodes, thecamoebians and sediment properties [Masters of Science, Dissertation]. - 450 pp., University of Winnipeg.

PosadA, D. (2008): jModelTest: Phylogenetic Model Averaging. - Mol. Biol. Evol. 25: 1253-1256.

Nübel, U.; Garcia-Pichel, F. \& Muyzer, G (1997): PCR Primers to Amplify 16S rRNA Genes from Cyanobacteria. - Appl. Environm. Microbiol. 63: 3327-3332.

Richmond, K. (1997): Paleolimnological analysis of sediments from Killarney Lake, Manitoba [Masters of Science, Dissertation]. - 96 pp., University of Manitoba.

Romo, S. \& Miracle, M.R. (1994). Population dynamics and ecology of subdominant phytoplankton species in a shallow hypertrophic lake (Albufera of Valencia, Spain). - Hydrobiologia 273: 37-56.

Ronquist, F. \& Huelsenbeck, J.P. (2003): MrBayes 3: Bayesian Phylogenetic inference under mixed models. - Bioinformatics 19:1572-1574.

RÜdiger, W.; Wagenmann, R. \& Muckle, G. (2007): Investigation of C-phycoerythrin from the cyanobacterium Pseudanabaena W 1174. - Arch. Microbiol. 127: 253-257.

SAlKI, A. (2005): Lake Winnipeg http://www. climatechangeconnection.org/impacts/ LakeWinnipeg_referencelist.htm

Tamura, K.; Peterson, D.; Peterson, N.; Stecher, G.; NeI, M. \& Kumar, S. (2011) MEGA5: Molecular Evolutionary Genetics Analysis using Maximum Likelihood, Evolutionary Distance, and Maximum Parsimony Methods. - Molecular Biology and Evolution 28: 2731-2739.

Watson, S.; Guo, J.; Klawunn, P.; Pascoe, Struger, J. \&
RAO, Y. (2009): Environment Canada Lake of the Woods Water Quality and Harmful Algal Blooms Assessment Initiative: Year I. LOWRF, Fort Francis, March 2009.

Whitton, B.A. \& Peat, A, (1969): On Oscillatoria redekei van Goor. - Arch. Microbiol. 68: 362-376.

YANG, Z. \& TELLER, J.T. (2005): Modeling the history of Lake of the Woods since 11,000 cal yr B.P. using GIS. - J. Paleolimnol. 33: 483-498.

ZHANG, W. \& RAO, Y. (2011): Application of a eutrophication model for assessing water quality in Lake Winnipeg - J. Great Lakes Res. Doi:10.1016/j.jglr.2011.01.003.

Zhang, W.; Rao, Y.; Watson, S.B.; Chittibabu, P. \& Huang, A. (In prep): Modelling of hydrodynamics and water quality in Lake of the Woods.

Zwart, G.; Kamst-van Agterveld, M. P.; van der WerffStaverman, I.; Hagen, F.; Hoogveld, H. L. \& Gons, H.J. (2005): Molecular characterization of cyanobacterial diversity in a shallow eutrophic lake. - Environm. Microbiol. 7: 365-377.

(C) Czech Phycological Society (2012)

Received July 17, 2011

Accepted September 11, 2011

Supplementary material

the following supplementary material is available for this article:

Fig. S1. (A) initial cultures November 2009 grown in Jüttner Media at $10{ }^{\circ} \mathrm{C}$ (B) cultures from July 2010 grown under $10^{\circ} \mathrm{C}$ and $20^{\circ} \mathrm{C}$ and low and high light. Notice visible pigment shift from red to green.

Table S2. Taxon, strain, accession number and genetic marker of strains used in this study.

Table S3. Summary statistics, Pseudanabaena rutilusviridis cell dimensions for red phenotype, grown under low light (RLL) and green phenotype, grown under high light (GHL).

This material is available as part of the online article (http://fottea.czechphycology.cz/contents) 